\title{
The Sosio-Economic Impact of Covid-19 Pandemic in Lhokseumawe City
}

\section{Angga Syahputra ${ }^{1}$, Mukhtasar ${ }^{2}$}

anggasyahputra@iainlhokseumawe.ac.id, mukhtasar@iainlhokseumawe.ac.id

1,2 Departement Islamic Banking Faculty of Economics and Islamic Business, IAIN Lhokseumawe DOI http://dx.doi.org/10.22219/sospol.v6i2.12799

\begin{abstract}
In the midst of government preventive efforts to implement health protocols, public activities of the Lhokseumawe City are still running normally. Whereas based on theory and former studies, the outbreak of Covid-19 caused social and economic changes affected activities of people around the world. By descriptive qualitative method, this study aims to analyze how the impact of local government policies to the socio-economy activities of the Lhokseumawe people and what factors influenced the response of Acehnese in the pandemic situation. Data were obtained through interview, observation to the public area, and library research on the impact of the pandemic to the society. It examines that Lhokseumawe City government policies such as imposing curfews, prohibiting gatherings in Cafe, and social distancing have received less response from the public. Community activities in trading, worshiping and social interaction tend not to be affected by information on the highly spreading of Covid-19 in this city. However, school and office activities relatively follow Central Government policies. The responses of Acehnese people relates to intersubjective background. The virus is a creation of God and the current situation reminds them to further increase their worship and not to be afraid to carry out normal activities. Even if they die, it is part of their destiny. Thus, the results of the study provide support for local governments to increase cooperation with Ulama in providing education to the public, increasing literacy for the spread of Covid-19, and the possibility of applying legal sanctions.
\end{abstract}

\begin{abstract}
Abstrak
Di tengah himbauan pemerintah untuk melakukan pembatasan sosial berskala besar dan upaya-upaya pencegahan untuk menerapkan protokol kesehatan, aktifitas sosial dan ekonomi masyarakat Kota Lhokseumawe masih berjalan normal. Padahal berdasarkan teori dan publikasi para pakar, merebaknya Covid-19 seharusnya membawa perubahan dalam aktifitas sosial dan ekonomi masyarakat di seluruh dunia. Dengan metode kualitatif deskriptif, penelitian ini bertujuan menganalisis bagaimana dampak kebijakan pemerintah dalam situasi pandemi terhadap aktifitas masyarakat Lhokseumawe dan faktor-faktor yang mempengaruhi pemahaman masyarakat dalam merespon situasi pandemi. Data diperoleh melalui wawancara, obeservasi penulis terhadap area publik dan studi pustaka terhadap beragam publikasi ilmiah yang menganalisis dampak pandemi terhadap berbagai aspek sosial masyarakat. Hasil studi menunjukkan kebijakan pemerintah Kota Lhokseumawe seperti pemberlakuan jam malam, larangan berkumpul di kafe, dan social distancing untuk menurunkan tingkat kematian akibat pandemi kurang mendapat respon dari masyarakat. Aktifitas masyarakat dalam berdagang, beribadah, dan berinteraksi sosial cenderung tidak terpengaruh dengan informasi penyebaran Covid-19. Namun aktifitas sekolah dan perkantoran relatif mengikuti kebijakan Pemerintah Pusat. Sikap masyarakat Lhokseumawe dilandasi oleh keyakinan mereka bahwa virus adalah ciptaan Tuhan dan situasi wabah mengingatkan mereka untuk lebih meningkatkan ibadah serta tidak perlu takut untuk beraktifitas normal. Andaipun mereka mati oleh wabah, hal itu sudah menjadi bagian dari takdir. Dengan demikian, hasil studi memberikan dukungan kepada pemerintah daerah untuk meningkatkan kerja sama dengan para Ulama dalam memberikan edukasi kepada masyarakat, meningkatkan literasi terhadap penyebaran Covid-19, dan kemungkinan untuk penerapan sanksi yang lebih tegas.
\end{abstract}

Keywords

Aceh, COVID-19,

Impact, Local

government, Socio-

economic

Article History

Received July 21, 2020

Revised October

7, 2020

Accepted October

10, 2020

Published

November 4, 2020

\section{Corresponding}

Author

Angga Syahputra.

Faculty of

Economics and

Islamic Business -

IAIN

Lhokseumawe, Jl.

Medan-Banda

Aceh, Alue Awe,

Lhokseumawe,

Indonesia. 24352 
Copyright (C) 2020, Angga Syahputra, Mukhtasar

This is an open access article under the CC-BY-SA

license
ISSN 2088-8090 (Print) ISSN 2597-6648 (Online)

Sospol: Jurnal Sosial Politik

Vol 6 No 2 (2020), pp.253-266

\section{Introduction}

Corona Virus Disease-19 (Covid-19) or known as the Corona Virus was first discovered in Hubei Province precisely at a marine animal and fish market in Wuhan City, China. The Chinese government released the first case of Covid-19 on December 31, 2019, but the medical journal The Lancet, published a study conducted by Chinese researchers claiming that the first Corona Virus case occurred on December 1, 2019, far earlier than a statement issued by the Chinese Government. The initial hypothesis released by WHO, the World Health Organization, was that the spread of the virus was transmitted from live animals to humans originating from the market. No one thought this virus would become a pandemic that spread almost all over the world (World Health Organization, 2020).

As a result of Covid-19, Indonesia's economy is predicted to grow negatively by $0.4 \%$ which is the worst scenario. The economic sector most affected by COVID-19 is the household sector (Susilawati, Falefi, \& Purwoko, 2020). The biggest problem in Indonesia today is the lack of awareness about the dangers of this virus in the community. Government appeals to minimize mobility and travel outside the home are difficult to implement in Indonesia (Yunus \& Rezki, 2020). This is because some workers have their respective responsibilities with the work that is in their workplace (Novida, Dahlan, \& Hudaa, 2020).

The policies of various countries in protecting their citizens and combating this epidemic now have an impact on the socio-economy of each region with different conditions. Socio-economics is an activity that is associated with meeting the needs of the community concerning clothing, food, health, education, and employment. Some policies set by the government today such as temporarily closing flights to and from the country suspect Covid-19, ordering to work from home, closing schools and colleges, social distancing, calling not to travel outside the house if not urgent, and avoid crowds.

The local government through Lhokseumawe Mayor's Appeal Number 264 of 2020, has also given an appeal about the Temporary Stopping/Closing of Tourist Attractions and Other Crowd Centers due to encourage the people to stay at home during the current situation. The Lhokseumawe is a very strategic city, located halfway between Banda Aceh and Medan. Dealing with the increasing number of Covid-19 patients, mobilization of people from Banda Aceh, Medan and surrounding areas get special attention from the local government of Lhokseumawe.

The people of Lhokseumawe City are used as research objects because this city is an industrial city which is known to be crowded with migrants from various cities in Indonesia. There are various large companies in Lhokseumawe City such as PT. Arun, PIM, paper processing and so on, where most of the workers come from outside this city. The large number of out-of-town residents who enter and leave the city has made the city government issue various policies to protect its citizens from the spread of the Covid-19 virus, it's just that the researcher's observations do not affect the socio-economic activities of the community. As of October 2020, Lhokseumawe City is still in the red zone, but the latest data for this city for 15 days has zero ODP and PDP patients (Bahri, 2020c). Previous studies have shown that there is a strong influence between the spread of bird flu and the socio-economic activities of the community. In addition, there was a decrease in productivity in the economic sector. Other 
impacts are also felt by various business sectors such as the poultry industry, tourism, hospitality, trade and transportation (Mulyani, 2012).

\section{Socio-economic Perspective}

In the socio-economic theory of Dahlgren and Whitehead (1991) that there is an influence between the spread of disease on the socio-economic activities of an area, where the community does not support preventive measures it will cause negative things to society. Surprisingly, the observations of researchers in the field, this theory is contrary to what happened to the socio-economic activities in Lhokseumawe City. Various policies issued by the Lhokseumawe City Government, ranging from limiting social activities, closing schools and orders to work from home to imposing curfews, do not affect the socio-economic activities of the Lhokseumawe City community. Furthermore, Kresna and Akhyar (2020) reveal that doing psychological distancing and limiting social activities greatly affects the spread of the Covid 19 virus. anticipations that need to be taken to protect the community from the widespread impact of Covid-19. This impact is of course not only on health factors, but will spread to various sectors (Yunus \& Rezki, 2020).

In addition to socio-economics, the Covid-19 pandemic has caused serious threats to physical health and human life. Covid-19 also triggers various psychological problems, such as panic disorder, anxiety and depression. There needs to be a concerted effort and the role of the government to minimize the deep trauma of the Covid-19 incident. The Lhokseumawe City Government needs to prepare trauma experts, academics, psychologists to play an important role in this crisis, because they have the ability and knowledge to provide support and care during this pandemic and into the future. This pandemic is a situation that we have never experienced before, and will certainly leave a threat after this pandemic ends. For this reason, the government and the community must fight together by working hard, innovating, to protect and care for the community against the impact of Covid-19 (Horesh \& Brown, 2020).

The current focus on transmission of COVID-19 infection worldwide may be able to divert public attention from the psychosocial consequences of outbreaks in affected individuals and in the general population. Though mental health problems that arise related to this global event can develop into long-term health problems, isolation and stigma. Global health measures must be implemented to deal with psychosocial stress, especially those related to isolation/quarantine activities, fear and vulnerability in public/public places. Inclusive responses worldwide must include a focus on the mental health impacts of patients and the general population. Information from the media and social networks must be tightly controlled and the public supporting psychological interventions promoted globally (Torales, O'Higgins, Castaldelli-Maia, \& Ventriglio, 2020).

Previous research shows an increase in negative emotions (anxiety, depression, and anger) and sensitivity to social risks, as well as a decrease in positive emotions (Oxford happiness) and life satisfaction after the announcement of the Covid-19 pandemic in China. What's more, people show more attention to health and family, and less attention to holidays and friends (Li, Wang, Xue, Zhao, \& Zhu, 2020).

This is certainly interesting to study further in this study, when people in other parts of the world prepare themselves to avoid this outbreak, the people of Aceh are still carrying out 
their activities normally. In general, this study will look at the social and economic impacts of the people of Lhokseumawe City, the policies taken by the government to protect the people which ultimately lead to the welfare of the people in Lhokseumawe City. This made researchers interested in studying the impact of Covid-19 on the socio-economy of Lhokseumawe City. Does the pandemic affect the socio-economic activities of the people of Lhokseumawe City, or does it have no impact at all, the causes and things that stakeholders need to do?

\section{Methods}

The method used in this research is qualitative method. The steps taken by researchers used the method of observation and literature review. Observations were made by researchers by directly observing general symptoms, social events or phenomena, patterns, and certain types of behavior, especially those related to the socio-economy in Lhokseumawe City after the stipulation of Covid-19 as a pandemic. The object that becomes the research is the people of Lhokseumawe City who are directly observed by researchers in carrying out socio-economic activities, such as work, school, going to the market, trading, gathering at coffee shops/cafes, and religious activities such as worshiping at mosques/meunasah. This city is included in the red zone for the spread of Covid-19, the government has tried to implement various policies but socioeconomic activities still appear to be running normally.

This research is also equipped with a literature review to enhance the results of this study with relevant theories to the problem under study. Literature reviews are taken from books, articles, previous scientific researches, as well as the latest news from websites that complement this study.

\section{Result and Discussion}

The existence of Covid-19 caught the attention of the world, there were ordinary ones who responded to it, there were those who handled it very seriously, there were also those who did not want to know. More and more spread from day to day make concrete steps must be taken in anticipation. Some small things that change from the social life patterns of our society, for example, appear when talking in a home or office environment, we are reluctant to shake hands. In addition to being reluctant to shake hands, we also maintain a safe distance of 1-2 meters with the speaker (Bariah, 2020). The Acehnese in general, especially the residents of Lhokseumawe City, not only build vertical ritual relationships, but also build horizontal relationships in social, economic and even political contexts. This arrangement of socio-political life is something of worship value in the concept of Acehnese society (Nazaruddin, 2014).

The Lhokseumawe City Government itself in deterring Covid-19 issued a number of rules, the initial step with the issuance of Lhokseumawe Mayor's Call Number 264 of 2020 concerning Temporary Termination/Closing of Tourist Attractions and Other Crowd Centers in the Lhokseumawe Government Area on March 20, 2020. Not long after the circular published, on March 26, 2020, the Government of Aceh confirmed the first positive case of Corona who died at Zainoel Abidin Hospital. Male patients who tested positive for the Corona virus had a history of trips to Surabaya and Bogor (Firmansyah, 2020). This patient was previously a referral from Arun Hospital, Lhokseumawe City. 
Copyright (C) 2020, Angga Syahputra, Mukhtasar This is an open access article under the CC-BY-SA license

The publication of the Lhokseumawe Mayor's Appeals and the findings of the first Covid-19 case in the Serambi Makkah Country did not necessarily change the socio-economic situation of its citizens. The results of observations by researchers, not much change after these two things. Conditions that seem different are only seen in school activities and government agencies. School activities have indeed been stopped since March 16, 2020 by the Government $\mathrm{f}$ Aceh through Plt. The Governor of Aceh Province to answer Presidential Decree Number 7 of 2020 concerning Task Force for the Acceleration of Handling Corona Virus Disease 2020 (COVID-19). While for government agencies, Nova implements a work policy with a shifting system and some work from home starting March 22, 2020. Campuses under the ministry follow the rules issued by the relevant ministries, namely online lectures.

Apart from schools and several government agencies, no significant change in activities has been seen since the appeal was published. The streets of Lhokseumawe City still look crowded with people who are in harmony. The streets seem crowded, but only a few people use masks as recommended by the government, while in the market masks are difficult to obtain, even if there are very expensive mask prices. Other activities that appear to be running normally are the mosque and meunasah (a building in the village that functions as a place of religious worship, religious education, deliberation and so on in Aceh). This place of worship is still full of worshipers for congregational prayers. Most people think that this is the time to draw closer to the God -Allah SWT, so the mosque must not be empty. Some others consider this plague to be God's destiny, so that even if you have to die, it's better to die during prayer.

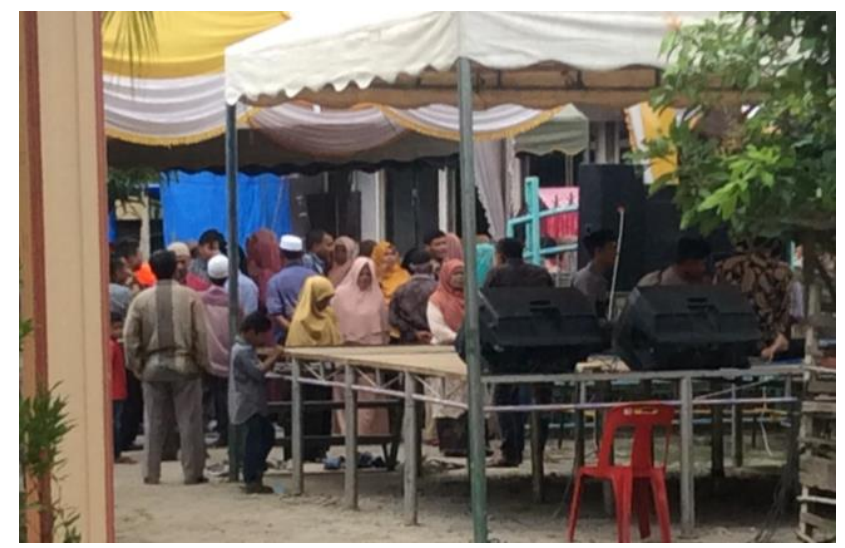

Figure 1. The party is still going on after the Covid-19 pandemic

Likewise, with the people who organized the party, it seemed that they were still reluctant to obey the circular of the Mayor of Lhokseumawe. The author's observation mentioned at Figure 1, the people who participated in the baroe and linto baroe activities did not even follow the Health protocol at all, such as not wearing a mask, not keeping a distance, and gathering in a crowd. Some party activities were even forced to be dissolved by the Geuchik Gampong (for village heads in Acehnese terms) together with Satpol PP, TNI and Polri devices.

On the other side, the religious scholars again made a tradition of the Acehnese people in rejecting reinforcements by parading torches around the village. The torch marches on the dzikir and recites verses of the Alquran are old traditions of the Tanab Rencong community which have been handed down from generation to generation. This tradition was once carried out 
when ta'eut (disease that attacks humans and animals) attacked the Aceh region. This tradition is known as Jak Hoi Qulja (a tradition of the people of Aceh around the village with a torch chanting read Surah Al-Isra: 81. This tradition has been carried out by the Acehnese people for generations). This activity began by reading Surah Yasin after the Maghrib prayer in congregation for seven consecutive days at the meunasah. Besides reading Surah Yasin, the community also prayed together and performed the circumcision prayer. After that the community turned on the panyoet surungkeng (another term for a torch that is used when a procession around the village is carried out to repel a plague that is believed by the people of Aceh.) to go around the village while reading "Waqul jaa-al haqqu wazahaqal baathilu, innal baathila kaana zahunqa." The community believes by asking Allah for help through this tradition, the Covid-19 outbreak will end in the Land of Aceh.

In order to minimize the spread of Covid-19 and the community's insignificant response to previous appeals, the Government of Aceh published a Joint Decree on the Aceh Regional Leadership Coordination Forum on the Application of a Curfew in Handling Corona Virus Disease - 19 in Aceh on March 29, 2020 as followed: 1) The community does not carry out activities outside the house from 20.30 WIB - 05.30 WIB; 2) The manager of business activities does not open a coffee shop/café, food and drink, markets, supermarkets, malls, karaoke, game rides, entertainment venues, tourist attractions and creations, sports venues, other business places and public transportation on the application of the curfew except for public transportation that serves the community and/or the community's basic needs, is equipped with a letter of assignment or a document that explains the work activities; and 3) Implementation takes effect from March 29, 2020 until May 29, 2020.

During the curfew, the streets seemed quiet in Lhokseumawe City. Activities of shops, centers, cafes, coffee shops and other businesses seem closed. Hospitals and pharmacies are still allowed to open during curfew. Every citizen who is forced to work must have a letter of assignment or a statement of the needs of the citizen, but this does not apply to residents who are sick and must be taken to the hospital.

Lhokseumawe District Police mobilized a team of 50 joint personnel. Patrol personnel consisted of Brimob, TNI, Satpol PP, and personnel from Lhokseumawe Regional Police. If there are people who leave without the interests referred to in the circular, they will be asked to return home humanist. Likewise, for cafes or coffee shops and businesses found to be still open, at the initial stage they will be asked to close persuasively. However, if it has been warned to remain operational, firm action will be taken (Bahri, 2020a).

The atmosphere at noon seems that the community is still doing normal activities as usual. Normal activities are also not accompanied by health measures recommended. The market as a trading activity is still crowded by residents to buy their daily needs, as well as the shopping center is still as usual. In the afternoons when the curfew is imposed, coffee shops or cafes are still visited by residents, but the number has drastically decreased. This is because the Lhokseumawe City Government has called for cafes, restaurants, coffee shops to abolish dine in, and replace it with take away.

Five days after the curfew in the Aceh region, on April 4, 2020, the Aceh Regional Leadership Coordination Forum issued a circular on Revoking the Curfew Implementation and Accelerating the Handling of Corona Virus Disease 2019: 1) Revoke the Joint Information 
Coordination Forum of the Aceh Regional Leadership on the Application of the Curfew in Handling Corona Virus Disease - 19 in Aceh; 2) Continuing the acceleration of handling Covid19 such as staying at home, worshiping at home, studying at home, working at home, and also avoiding crowds, public facilities, including religious activities that involve many people; and 3) Management of economic activities must apply the rules of maintaining distance between fellow physical distancing.

The reason given by Nova (Acting Governor of Aceh), "Because it has not been followed by a good social program, we plan to stop curfew until then later we return it. Many of the SMEs trade at night". This has indeed been previously complained by people who open businesses at night, the Aceh Government seems in a hurry to issue the policy and without warning. Some traders who sell at night when questioned by the authors reveal that they have never received a notification from the Government of Aceh for the imposition of a curfew, so that the sudden implementation, without careful preparation, makes their businesses lose money and cannot prepare other options for their business (Redaksi, 2020).

In terms of the movement of people out of town after the lifting of the curfew, there was a decline in the number of inter-city bus passengers in Lhokseumawe Type A Terminals. The Coordinator of Lhokseumawe Type A - Terminal Service Unit said that the changes had taken place since the curfew was imposed until the curfew was abolished. The number of passengers specifically going to Medan dropped dramatically, before the Covid-19 outbreak, this terminal departed 70 buses per day, but now only 8 buses (Siti Nurhasyimah, 2020). The socioeconomic condition of the Lhokseumawe community seems to be proceeding normally, especially since Aceh was declared free from Covid-19. This makes people more confident to do activities outside the home freely. Only Lhokseumawe City Government is currently intensifying patrols to the public to use non-medical masks or cloth masks. On the streets, elements from the TNI, Polri, Satpol PP and Dishub raided people who did not wear masks when they were out of the house.

On the other hand, the Acehnese's faith in the efforts previously made, by enlivening the mosque and meunasah, making joint study, and the tradition of parading torches around the village became stronger. They believe that the Aceh region which is currently free from Covid-19 is inseparable from the effort to draw closer to Allah. The amount of information about new Covid-19 patients is increasing every day and more data about transmission and route, reservoir, incubation period, symptoms and clinical outcomes, including survival rates, are collected from various worlds (Corman et al., 2020).

The best treatment options for viruses are still unknown. Given the high case fatality rate and potential global virus spread, there is an urgent need to develop effective therapies for this virus (Al-tawfiq, Momattin, Dib, \& Memish, 2020). The Lhokseumawe City Government is expected to collaborate with elements of the Gampong apparatus in preventing and breaking the chain of the spread of Covid-19 by providing education to the public. Through clerics and village officials, it is hoped that the message to be conveyed by the government will get a good response, rather than the government merely issuing circular letters.

In everyday life the people of Lhokseumawe City are still reluctant to implement health protocols using masks. And as stated by WHO, using masks effectively minimizes the impact of 
the spread of Covid-19. This is to avoid droplets that come out of patients who are positive for Covid-19 but do not have any symptoms (Chan et al., 2020).

The market which is still crowded with safe and unlimited community interaction is a negligence by the people of Lhokseumawe. In addition to avoiding contact with sick people, especially those who cough, avoiding visiting markets and living animals is a solution to breaking the chain of the spread of Covid-19 (Huang et al., 2020). We need to promote prevention rather than treatment, because until now there has been no safe and reliable vaccine or vaccine combination to protect positive patients. Another reason for the importance of prevention efforts is the high cost of clinical trials, especially for commercial purposes. Various trials are currently underway to ensure the development of a safe, effective and appropriate vaccine (McAleer, 2020).

At least from the data of the Lhokseumawe City Government, there are 5000 residents who have been directly affected by the economy due to Covid-19 (Bahri, 2020b). According to the Mayor of Lhokseumawe, this is a result of policies and instructions issued in order to anticipate the spread of the Covid-19 Virus. The impact of other social vulnerabilities can make people take three interrelated actions, namely apathetic actions, irrational actions, and criminal actions. This can be seen in the phenomenon of the Lhokseumawe city community today. So what happens to the community is the culmination of the social vulnerabilities that are currently being faced by the community.

The first one is apathy. In apathetic actions we can see the actions of the people who do not care about the government's instructions for physical distancing and not going back to their hometowns. In fact, physical distancing is not effective. There are still many Lhokseumawe people doing gathering activities and other crowd activities. Besides that, there are many migrants in Lhokseumawe City today who choose to return to their hometowns. Likewise, Lhokseumawe residents who wander outside the area also chose to return to Lhokseumawe City. This act of returning home to the community has actually increased the number of Covid-19 cases and the distribution of its territory, both ODP (Insider Monitoring) status, PDP (Patient Under Supervision) and Covid-19 Suspect. Socially the actions taken by these people cannot be said to be wrong (non-ethical). Because what people do is an instinctive response to the social vulnerability that they are facing. Therefore, it is the government's job to be able to make people continue to have social resilience so as not to act apathetic when the nation and country are confronted by the Covid-19 pandemic.

The second one is irrational action. In irrational actions, not a few people believe in various medicinal ingredients and prevention methods so as not to be exposed to Covid-19 even though there is no evidence of scientific research. For example, the Lhokseumawe community believes that drinking betel leaf boiled water can increase the body's immunity and help prevent Covid-19 transmission. What people do in the use of medicinal materials and certain methods to prevent the transmission of Covid-19 even though there is no evidence of scientific research is inseparable from the public attachment to ways (usage), habits (folkways), behavior (mores), and customs. (custom) that applies to the living environment. Sociologically, this social action is called traditional action.

Another irrational action, namely panic buying. In the observation of researchers, the upper economic circles in Lhokseumawe City since the circular for social restrictions, began to 
buy more goods than usual, but at other levels of society, everything seemed normal. The prices of basic necessities also appear to be no significant increase (Antara, 2020). Panic buying is a response of the community to not experience difficulties in meeting their daily needs, and this has actually made the prices of various needs soar and become a step due to illegal hoarding (Warta Ekonomi, 2020).

The next irrational action, which initially people understand the high risk (such as high interest and data theft), is not to apply for loans to moneylenders, both moneylenders based on conventional loans and online loans (fintech). Like it or not, people apply for loans to moneylenders as a survival mechanism for themselves and their families when economic conditions are uncertain in the Covid-19 pandemic. The practice of moneylenders in Lhokseumawe City is also fairly massive, especially since the Covid-19 outbreak, many parties have offered money loans with a cooperative motive, even though the system in effect is a moneylender system. The community must be able to pay close attention to loans to legal moneylenders and must be able to anticipate the risks. If not, the act of borrowing from moneylenders will add new problems for the community (Majid, 2020).

The third one is criminal acts. The most worrying thing about the social vulnerability of the Covid-19 pandemic is the criminal acts committed by the public (Serambi, 2020). In social science the definition, criminal acts are acts that violate the law and harm themselves and others (victims) that disturb the balance, peace and order in the community. Forms of criminal acts that occur for example are theft, mugging, pickpocketing, bullying, looting, and even murder. A concrete example of a criminal action due to the Covid-19 pandemic can be seen in various news media that have begun to occur in other countries (such as Italy, India, China, America), even in Indonesia there have begun cases of theft with the motive of reducing income economy due to the Covid-19 pandemic (Kompas, 2020).

Criminal acts committed by the public as a result of the social vulnerability they face can be understood at least in three sociological contexts. First, basically the community is in a stable condition, the living systems operate smoothly and function. However, due to the Covid19 pandemic, this condition of stability and functioning was disrupted. To be able to be in a stable and functional position, for people who do not have access to capital properly, then a short road that is at risk will be done. Second, criminal acts occur because of the rules governing conflicting behavior. For example, the government instructed the public to carry out physical distancing, while the government did not prepare instruments to protect the resilience of people working in the informal sector. And third, criminal acts occur because of a vacuum of control or social control. For example, there are no strict sanctions and deterrent effects for those who use the condition of the Covid-19 pandemic for their own benefit and enrich themselves, such as the accumulation and falsification of hand sanitizer fluids and drugs which are then sold freely in the community (Tempo, 2020).

The Lhokseumawe city government needs to take preventive steps in the form of appeals, education and binding penalties to protect its citizens from the impact of the spread of Covid-19. This step can be imitated by the Chinese Government which is claimed to have successfully overcome the Covid-19 outbreak by taking several policies such as:: 1) The Government should pay more attention to vulnerable groups such as young people, the elderly, women and migrant workers, 2) Accessibility to medical resources and public health service 
systems must be further strengthened and enhanced, especially after reviewing the initial handling and management of the Covid-19 epidemic, 3) National strategic planning and coordination for psychological first aid during major disasters, potentially delivered through remote treatment, must be established, 4) comprehensive crisis prevention system and interventions including epidemiological monitoring, screening, referral and targeted interventions must be built to reduce psychological pressure and prevent further mental health problems (Qiu et al., 2020).

On the other hand, fears of a new recession and financial collapse, times like these require strong and strong leadership in health care, business, government, and the wider community. Immediate relief measures need to be implemented and adjusted for those who might fall through a gap. Medium and long term planning is needed for how the economy is rebalanced and re-energized after this crisis. Extensive socio-economic development plans including sector-by-sector and ecosystem plans that encourage entrepreneurship so that those with strong and sustainable business models can be allowed to develop. It is wise if the government and financial institutions are currently re-evaluating the policies that have been taken at this time and ensure that whatever promises are needed are actually achieved and enjoyed by the community (Nicola, 2020).

Policy makers in various countries currently support policies to maintain extended social distance. Consequently, there is damage to social distance in the economy. The current recession in many countries is a reflection of the difficult choices that policy makers must make in choosing whether to save the economy before saving the people or saving the people before saving the economy and many countries choose the latter option. The curfew policy adopted by the Government of Aceh is actually appropriate, but poor preparation makes the policy criticized and received resistance from the community (Kompas, 2020). In some countries, the application of curfew effectively reduces the risk of the spread of Covid-19 such as in Makkah City - Saudi Arabia, United Arab Emirates and several other countries. Makkah and the United Arab Emirates were able to successfully implement a curfew with careful preparation, such as an appeal to the public, education and strict binding rules for violators of these rules (Reuters, 2020). In Indonesia, the East Java Province will now implement the same thing to reduce the level of distribution (Widarti, 2020).

In applying learning from home or known as online learning, the Lhokseumawe City Government policy is considered appropriate (Redaksi, 2020). The condition of the spread of Covid-19 that was so fast made students have to take days off. This condition has been applied by China at the beginning of the spread of Covid-19. The Chinese government calls this term Emergency Management, which includes maintaining social distance. School classes in China are suspended without stopping learning. Although in the process of implementation the advantages and disadvantages need to be carefully considered and studied (Zhang, Wang, Yang, \& Wang, 2020). Likewise, its application with students in Lhokseumawe has constraints such as many students and parents who do not master technology, access to internet networks that are still difficult, some households still do not have smartphones, making teachers have to be creative and smart to ensure their students can still learn at home. 
Copyright (C) 2020, Angga Syahputra, Mukhtasar

This is an open access article under the CC-BY-SA

license
ISSN 2088-8090 (Print) ISSN 2597-6648 (Online)

Sospol: Jurnal Sosial Politik

Vol 6 No 2 (2020), pp.253-266

\section{Conclusion}

This study concluded that the Covid-19 pandemic did not affect the activities of the people of Lhokseumawe, both socially and economically. The Acehnese carry out their social activities normally in the public areas, such as traditional markets, shopping centers, and mosques. But the activities in the school and office relatively respect to the policies of the central government.

The data released of pandemic Covid-19 has recently increased in the city of Lhokseumawe, both in terms of PDP and the mortality rate, does not necessarily affect the activity of the society. People argued that the diseases is kind of challenge from the God that made the Muslim must get closer to worship and praying. Most of Acehnese people did not belive in the existance of virus Covid-19, so they are reluctant to carry out any policies that are conveyed by the government.

Finally, this study encourages Lhokseumawe local government to pay attention to several actions such as providing education toward the impact of Covid-19 by collaborating with Ulama, increasing public literacy, and strengthened law enforcement. The ignorance of citizens will ultimately affect economic activities that have an impact on the welfare of the community.

\section{References}

Al-tawfiq, J. A., Momattin, H., Dib, J., \& Memish, Z. A. (2014). Ribavirin and interferon therapy in patients infected with the Middle East respiratory syndrome coronavirus: an observational study. International Journal of Infectious Diseases, 20(January), 42-46. doi: 10.1016/j.ijid.2013.12.003.

Antara. (2020). Disperindag Aceh Minta Masyarakat Tidak Borong Makanan. Retrieved October 31, 2020, from Antara Aceh website: https://aceh.antaranews.com/berita/128770/disperindag-aceh-minta-masyarakat-tidakborong-makanan

AJNN. (2020, April 4). Alasan Pemerintah Aceh Mencabut Sementara Perberlakuan Jam Malam.

Retrieved October 10, 2020, from ajnn.net website:

https://www.ajnn.net/news/alasan-pemerintah-aceh-mencabut-sementara-

perberlakuan-jam-malam/index.html

Bahri, S. (2020a, March 31). Saat Jam Malam, Sejumlah Ruas Jalan di Lhokseumawe Ditutup, Hanya Apotek dan RS yang Boleh Buka - Serambi Indonesia. Retrieved October 10, 2020, from serambinews.com website: https://aceh.tribunnews.com/2020/03/31/saatjam-malam-sejumlah-ruas-jalan-di-lhokseumawe-ditutup-hanya-apotek-dan-rs-yangboleh-buka

Bahri, S. (2020b, April 9). 5.000 Warga Lhokseumawe Terimbas Ekonomi Akibat Covid-19, Ini yang Dilakukan Pemko Lhokseumawe - Serambi Indonesia. Retrieved October 10, 2020, from serambinews.com website: https:/ /aceh.tribunnews.com/2020/04/09/5000-warga-lhokseumawe-terimbasekonomi-akibat-covid-19-ini-yang-dilakukan-pemko-lhokseumawe

Bahri, S. (2020c, June 8). Meski Masuk Zona Merah, Lhokseumawe Sudah Masuki 15 Hari Nol ODP dan PDP - Serambi Indonesia. Retrieved October 10, 2020, from serambinews.com website: https://aceh.tribunnews.com/2020/06/08/meski-masuk- 
Copyright (C) 2020, Angga Syahputra, Mukhtasar This is an open access article under the CC-BY-SA license
ISSN 2088-8090 (Print) ISSN 2597-6648 (Online)

Sospol: Jurnal Sosial Politik

Vol 6 No 2 (2020), pp.253-266

zona-merah-lhokseumawe-sudah-masuki-15-hari-nol-odp-dan-pdp

Bariah, C. (2020, March 21). Pengaruh Corona terhadap Kehidupan Sosial Masyarakat - Halaman 2 - Serambi Indonesia. Retrieved October 10, 2020, from Serambinews.com website: https://aceh.tribunnews.com/2020/03/21/pengaruh-corona-terhadap-kehidupansosial-masyarakat?page $=2$

Chan, J. F. W., Yuan, S., Kok, K. H., To, K. K. W., Chu, H., Yang, J., ... Yuen, K. Y. (2020). A familial cluster of pneumonia associated with the 2019 novel coronavirus indicating person-to-person transmission: a study of a family cluster. The Lancet, 395(10223), 514523. https://doi.org/10.1016/S0140-6736(20)30154-9

Corman, V. M., Landt, O., Kaiser, M., Molenkamp, R., Meijer, A., Chu, D. K. W., ... Drosten, C. (2020). Detection of 2019 novel coronavirus (2019-nCoV) by real-time RT-PCR. Eurosurveillance, 25(3), 1-8. https://doi.org/10.2807/1560-7917.ES.2020.25.3.2000045

Firmansyah, T. (2020, March 26). Aceh Konfirmasi Kasus Pertama Corona, Korban Meninggal | Republika Online. Retrieved October 10, 2020, from Republika.co.id website: https://republika.co.id/berita/q7sgzu377/aceh-konfirmasi-kasus-pertama-coronakorban-meninggal

Horesh, D., \& Brown, A. D. (2020). Traumatic Stress in the Age of COVID-19: A Call to Close Critical Gaps and Adapt to New Realities. American Psychological Association, 12(4), 331335. http://dx.doi.org/10.1037/tra0000592

Huang, C., Wang, Y., Li, X., Ren, L., Zhao, J., Hu, Y., ... Cao, B. (2020). Clinical features of patients infected with 2019 novel coronavirus in Wuhan, China. The Lancet, 395(10223), 497-506. https://doi.org/10.1016/S0140-6736(20)30183-5

Kompas. (2020). Dilema Jam Malam di Tengah Wabah Corona, di Aceh Hanya Bertahan Sepekan. Retrieved October, 312020 from kompas.com website: https://regional.kompas.com/read/2020/04/09/06070001/dilema-jam-malam-ditengah-wabah-corona-di-aceh-hanya-bertahan-sepekan?page $=$ all

Kompas. (2020). Tak Hanya Wabah Covid-19, 'Wabah' Kriminal di Chicago Juga Meningkat. Retrieved October, 312020 from kompas.com website: https://www.kompas.com/global/read/2020/04/12/093740870/tak-hanya-wabahcovid-19-wabah-kriminal-di-chicago-juga-meningkat?page=all

Kresna, A. \& Ahyar, J. (2020). Pengaruh Physical Distancing Dan Social Distancing Terhadap Kesehatan Dalam Pendekatan Linguistik. Jurnal Syntax Transformation, 1 (4), 14-19. DOI: https://doi.org/10.46799/jurnal\%20syntax\%20transformation.v1i4.42

Li, S., Wang, Y., Xue, J., Zhao, N., \& Zhu, T. (2020). The impact of covid-19 epidemic declaration on psychological consequences: A study on active weibo users. International Journal of Environmental Research and Public Health, 17(6). https://doi.org/10.3390/ijerph17062032

Majid, S.A. (2020). Genderang Perang Melawan Rentenir. Retrieved October 31, 2020, from acehsatu website: https://acehsatu.com/genderang-perang-melawan-rentenir/

McAleer, M. (2020). Prevention Is Better Than the Cure: Risk Management of COVID-19. Journal of Risk and Financial Management, 13(3), 46. https://doi.org/10.3390/jrfm13030046

Nazaruddin, M. (2014). Dimensi pembentuk kesadaran identitas keacehan dan citra diri Aceh. 
Copyright (C) 2020, Angga Syahputra, Mukhtasar This is an open access article under the CC-BY-SA license
ISSN 2088-8090 (Print) ISSN 2597-6648 (Online)

Sospol: Jurnal Sosial Politik

Vol 6 No 2 (2020), pp.253-266

Masyarakat, Kebudayan Dan Politik, $\quad$ 27(1), $\quad$ 44-54. http://dx.doi.org/10.20473/mkp.V27I12014.44-54

Novida, I., Dahlan, D., \& Hudaa, S. (2020). Pelatihan pencegahan wabah pandemi covid-19 dan pembuatan penyitasi tangan yang ekonomis. Jurnal Masyarakat Mandiri (JMM), 4(2), 193200. DOI: https://doi.org/10.31764/jmm.v4i2.1949

Qiu, J., Shen, B., Zhao, M., Wang, Z., Xie, B., \& Xu, Y. (2020). A nationwide survey of psychological distress among Chinese people in the COVID-19 epidemic: Implications and policy recommendations. General Psychiatry, 33(2), 1-4. https://doi.org/10.1136/gpsych-2020-100213

Reuters. (2020). Strategi ekstrem Arab Saudi, Mekah dan Madinah terapkan jam malam selama 24 jam! Retrieved October 31, 2020 from kontan.co.id website: https://internasional.kontan.co.id/news/strategi-ekstrem-arab-saudi-mekah-danmadinah-terapkan-jam-malam-selama-24-jam

Tribunnews Aceh. (2020). Kasus Kriminal Meningkat, Polres Lhokseumawe Tawarkan Pengawalan Gratis Kepada Warga. Retrieved October 31, 2020 from serambinews.com website: https://aceh.tribunnews.com/2020/07/22/kasus-kriminal-meningkat-polreslhokseumawe-tawarkan-pengawalan-gratis-kepada-warga

Susilawati, S., Falefi, R., \& Purwoko, A. (2020). Impact of COVID-19's Pandemic on the Economy of Indonesia. Budapest International Research and Critics Institute (BIRCI-Journal): Humanities and Social Sciences, 3(2), 1147-1156. https://doi.org/10.33258/birci.v3i2.954

Syaifuddin. (2020). Covid-19, Kerentanan Sosial, dan Gagalnya Physical Distancing. Retrieved October, $\quad 31 \quad 2020$ from $\quad$ Tempo website: https://kolom.tempo.co/read/1326074/covid-19-kerentanan-sosial-dan-gagalnyaphysical-distancing

Torales, J., O’Higgins, M., Castaldelli-Maia, J. M., \& Ventriglio, A. (2020). The outbreak of COVID-19 coronavirus and its impact on global mental health. International Journal of Social Psychiatry, 66(4), 317-320. https://doi.org/10.1177/0020764020915212

Warta Ekonomi. (2020). Apa itu Panic Buying?. Retrieved October 31, 2020 from wartaekonomi.co.id website: https://www.wartaekonomi.co.id/read280798/apa-itupanic-buying

Widarti, P. (2020). Pemkot Surabaya Berlakukan Pembatasan Aktivitas Jam Malam. Retrieved October 31, 2020 from bisnis.com website: https://surabaya.bisnis.com/read/20200715/531/1266625/pemkot-surabayaberlakukan-pembatasan-aktivitas-jam-malam

World Health Organization. (2020). Novel Coronavirus (2019-nCov) Situation Report 1. (JANUARY), 1-14. https://www.who.int/docs/default-source/coronaviruse/situationreports/20200121-sitrep-1-2019-ncov.pdf

Yunus, N. R., \& Rezki, A. (2020). Kebijakan Pemberlakuan Lockdown Sebagai Antisipasi Penyebaran Corona Virus Covid-19. SALAM: Jurnal Sosial Dan Budaya Syar-I, 7(3), 227238. https://doi.org/10.15408/sjsbs.v7i3.15048

Zhang, W., Wang, Y., Yang, L., \& Wang, C. (2020). Suspending Classes Without Stopping Learning: China's Education Emergency Management Policy in the COVID-19 Outbreak. Journal of Risk and Financial Management, 13(3), 55. 
Copyright (C) 2020, Angga Syahputra, Mukhtasar

This is an open access article under the CC-BY-SA

license
ISSN 2088-8090 (Print) ISSN 2597-6648 (Online) Sospol: Jurnal Sosial Politik Vol 6 No 2 (2020), pp.253-266

https://doi.org/10.3390/jrfm13030055

\section{Interviews}

Nurhasyimah, Siti. (2020). Lhokseumawe, July 1, 2020. 